\title{
TROPICAL MAIZE SYNTHETICS BREEDING IN MOISTURE-STRESS TOLERANCE FOR SMALL-SCALE FARMERS IN BRAZILIAN SEMI ARID REGIONS
}

\author{
ELTO EUGENIO GOMES E GAMA ${ }^{1}$, SIDNEY NETTO PARENTONI ${ }^{1}$, FREDERICO OZANAN \\ MACHADO DURÃES ${ }^{1}$, CARLOS EDUARDO PRADO LEITE ${ }^{1}$, MANOEL XAVIER DOS SANTOS ${ }^{1}$, \\ CLESO ANTÔNIO PATTO PACHECO ${ }^{1}$, ANTÔNIO CARLOS DE OLIVEIRA ${ }^{1}$
}

${ }^{1}$ Pesquisadores, Embrapa Milho e Sorgo. Caixa postal 151, CEP. 35701-970 Sete Lagoas, MG. E-mail: gamaelto@cnpms.embrapa.br (autor para correspondência).

Revista Brasileira de Milho e Sorgo, v.3, n.1, p.69-76, 2004

\begin{abstract}
The objective of this work was to evaluate 144 S2 progenies from each of two synthetic maize populations, Syndent and Synflint, from a breeding program for drought tolerance, to obtain synthetics with high yield potential and good agronomic performance in the semi-arid regions in Brazil. The $288 \mathrm{~S} 2$ progenies from the two synthetics were evaluated using a $12 \times 12$ lattice design with two replications in two conditions with water stress (WS) and non water stress (NS) in Janaúba, MG, Brazil, in 2000. The combining analysis of variance showed highly significant $(\mathrm{P}<0.01)$ effects in environments and progenies and their interaction for Synflint, and significant ones $(\mathrm{P}<0.05)$ in the interaction for Syndent. The estimates of the broad sense heritability of ear yield were: Synflint $h^{2}=0.382$ and 0.752 for WS and NS, respectively; Syndent $h^{2}=0.607$ and 0.635 for WS and NS, respectively. The genetic variance estimates were greater in NS than in WS environments. The error variance estimates were the greatest in WS x NS interaction for the two synthetics. The predicted responses to selection pointed out better gains for yield when selection is performed in NS rather than WS environments. Substantial variability exists in these two synthetics for drought tolerance and its characteristics, indicating that there is an opportunity for improving their tolerance via recurrent selection.
\end{abstract}

Key words: Zea mays L., synthetic, water stress, yield, maize.

\section{MELHORAMENTO DE SINTÉTICOS DE MILHOS TROPICAIS VISANDO TOLERÂNCIA À SECA PARA O SEMI-ÁRIDO BRASILEIRO}

RESUMO - O objetivo deste estudo foi avaliar 144 progênies $\mathrm{S}_{2}$ de cada um das duas populações sintéticas de milho, Syndent e Synflint, oriundas de programa de melhoramento para tolerância à seca, visando a obtenção de sintéticos com alto potencial produtivo e com bom comportamento agronômico sob condições de seca da região semi-árida do Brasil. As 288 progênies $\mathrm{S}_{2}$ dos dois sintéticos foram avaliadas usando-se um delineamento de látice 12 x 12 com duas repetições e em duas condições: com estresse de seca (WS) e sem estresse de seca (NS), em Janaúba, MG, Brasil, em 2000. Na análise de variância conjunta, foram detectados efeitos altamente significativos $(\mathrm{P}<0.01)$ para ambientes e progênies e para a interação entre eles para o Synflint, mas somente significante $(\mathrm{P}<0.05)$ para a interação para o Syndent. As estimativas para herdabilidade no sentido amplo para produção de espigas, para o Synflint, foram de $\mathrm{h}^{2}=0.382$ e 0.752 para WS e NS, respectivamente; e, para o Syndent, as estimativas foram $\mathrm{de}^{2}=0.607$ e 0.635 para WS e NS, respectivamente. As estimativas da variância 
genética foram maiores no NS que no WS ambientes. As estimativas para a variância do erro foram maiores para a interação WS x NS para os dois sintéticos. As respostas esperadas para a seleção foram direcionadas para melhores ganhos na produção quando a seleção é feita no ambiente NS que no ambiente WS. Existe suficiente variabilidade nos dois sintéticos para tolerância à seca e na expressão dos caracteres relacionados com a tolerância, indicando a viabilidade de ganhos na seleção para tolerância ao estresse de seca por meio de seleção recorrente.

Palavras chave: Zea mays L., sintético, seca, produção, milho.

In tropical regions, drought, low natural soil fertility, and biotic stress such as leafborer, among other effects, are major constraints for maize production. The northeastern region comprises $18,28 \%$ of Brazil's total area, and contributes to $5,32 \%$ of the national maize grain yield, with the highest incidence of drought and no uniform rainfall distribution (Santos et al., 1997). Most of the maize produced in this region comes from small farms and drought has been the main constraint, responsible for severe yield losses. Maize is the most important food crop in the region and the need to increase its production cannot be overemphasized. In marginal areas, as pointed out by Ceballos \& Pandey (1991 a, b), maize is generally cultivated as staple food, using little agronomic inputs, limited financial support and low resources.

Small-scale farmers in the tropical areas are usually people who suffer the most, due to droughts and other adverse natural conditions. Drought stress tolerant germplasms are expected to be very useful to small scale farms that grow maize in areas frequently affected by drought.

Drought stress occurs with different intensity at any plant development stage from germination to physiological maturity, being flowering the most critical stage in maize for drought stress (Hall et al. 1982, Bolaños \& Edmeades 1993).

A selection program for non-biotic stress tolerance should place emphasis on the importance of evaluation in stress and non-stress environments. The pre-flowering stress treatment caused genetic variability e.g., ears per plant, kernel weight, etc. Thus, severe water stress treatment reduces grain yield genetic variation (Bolaños \& Edmeades, 1997).

There is strong agreement that selection for yield under drought stress is lower than under non stress conditions, mainly because of reduction in heritability of yield under stress (Rosielle \& Hambling, 1981; Blum, 1988; Johnson \& Geadelmann, 1989). Thus selection would be carried out under both stress and non stress environments.

The type of progenies evaluated affects the rate of improvement and the ability to discriminate genotypes for stress tolerance. The self progenies as showed by many research results on yield improvement, are preferred over non inbred progenies, because heritability increases with levels of inbreeding (Bolaños \& Edmeads, 1997; Lamkey \& Hallauer, 1987).

The objectives of this study were to evaluate the genetics parameters that better estimate ear yield used in selection in self progeny trials under drought stress and non-stress conditions as part of a recurrent selection program for drought tolerance in two heterotic tropical maize synthetics.

\section{Material and Methods}

The Syndent was synthesized by the recombination of 13 elite dent type inbred lines of Tuxpeño germplasm (CIMMYT) and the Synflint through the recombination of 15 flint type inbred lines from Caribbean and Cateto germplasm (CIMMYT), in 1995. The selection began in 1996 and underwent 
3 cycles of full sib recurrent selection scheme in the rainy seasons at the Maize and Sorghum Research Center/Embrapa in Sete Lagoas, Minas Gerais State (MG), Brazil. Each cycle of full-sib selection required one year to complete.

In $1998200 \mathrm{~S} 1$ were obtained from each synthetic and the $\mathrm{S} 1$ families were prescreened under mild drought in Sete Lagoas. They were also selected for desirable plant characteristics and the selected ones were advanced to $\mathrm{S} 2$ by self pollination.

The superior 144 S2 progenies of each synthetic were grown for yield evaluation at the experimental station of Janaúba, Northern Minas Gerais, altitude $516 \mathrm{~m}$, latitude $15^{\circ} 47^{\prime} \mathrm{S}$ and longitude $43^{\circ} 18^{\prime} \mathrm{W}$, annual mean rainfall of $873,5 \mathrm{~mm}$, mean temperature of $24,7^{\circ} \mathrm{C}$ and mean relative humidity of $65 \%$, where drought stress could be managed by controlled irrigation during the hot rain-free season under two water regimes (environments). The soil was classified as latosol yellow, dystrophic and of clay texture. Each of the two 144 progeny sets were evaluated using a lattice design $12 \times 12$ with an inserted check entry (experimental double-cross hybrid with low tolerance to drought) and 2 replications, in $5 \mathrm{~m}$ long single-row plots, spaced $0,90 \times 0,20 \mathrm{~m}$ between row and plant within the rows, respectively. In the two areas $250 \mathrm{~kg} \mathrm{ha}^{-1}$ of 8:28:16 (NPK) plus Zn was applied at planting and $80 \mathrm{~kg} \mathrm{ha}^{-1}$ of $\mathrm{N}$ was side dressed 30 days after seed germination. The water regimes were, without water stress (NS) and with water stress (WS) and irrigation was suspended two weeks prior to anthesis and was reinitiated two weeks after flowering to ensure that kernels set under this stress would be filled. The soil depths and soil moisture depletions under the two treatments are illustrated in Figure 1. Low water supplied was associated with genotype sensitivity to drought since symptoms such as leaf rolling and low plant development were observed in the water deficient experimental area.
Data were collected for ear yield $\left(\mathrm{kg} \mathrm{plot}^{-1}\right)$. Statistical analyses of variance followed procedures described by Falconer (1989). Each experiment was analyzed separately as lattice design, and broadsense heritability of ear yield and predicted responses of yield of selection were calculated as:

Broad-sense heritability $h^{2}=\sigma^{2}{ }_{g} /\left(\sigma_{g}^{2}+\sigma^{2}{ }_{e} / r\right)$, for a single environment. Where $=\sigma_{\mathrm{g}}^{2}=$ Genetic variance; $\sigma^{2}=$ Error variance and $r=$ number of replication (Hallauer and Miranda Filho, 1981).

Predicted response to selection in $\mathrm{kg} \mathrm{plot}^{-1}$ was calculated as $\mathrm{R} \%=\mathrm{k} 3 / 2 \sigma_{\mathrm{A}}^{2}+(5 / 4) \mathrm{D}_{1} /\left(\sigma_{F}\right)$ where $\left(\sigma_{F}\right)$ is the phenotypic standard deviation of the progeny mean, and $\left(\mathrm{D}_{1}\right)$ covariance between additive and dominance effects of the homozygous. By assuming a standardized selection differential $(\mathrm{k})$ of 1.0, using the genetic variance instead $\left(\sigma^{2}{ }_{A}\right)$ additive variance and $\mathrm{D}_{1}$ equal zero, the expected progress values can be biased upward or downward (Personal communication C. L. Souza Junior). This parameter was calculated under the restrictions already mentioned.

Analysis for genotype distribution was performed on a water stress index (WSI) based on yield under drought condition to identify the most tolerant progenies to the moisture stress imposed in the experiments. The water stress index was calculated by using an equation modified based on Fisher \& Maurer (1978).

$\mathrm{WSI}=\left(\begin{array}{cc}\mathrm{H}_{2} \mathrm{O} & \text { DROUGHT }\end{array}\right) /\left(\begin{array}{cc}\bar{M} \mathrm{H}_{2} \mathrm{O} & \overline{M D R O U G H T}\end{array}\right)$

\section{Results and Discussion}

For the variable ear yield, results of the combined analysis of variance showed high significant differences $(\mathrm{P}<0.01)$ among the progenies of both synthetics, and the environments $\mathrm{x}$ progenies interaction were highly significant $(\mathrm{P}<0.01)$ and significant $(\mathrm{P}<0.05)$ for the Synflint and the Syndent, 
respectively (Table 1). The self progenies within each synthetics were genetically different and presented different yielding performance in both environments.

Ear yield means (Table 2) were high in both synthetics at non water stress conditions (NS), and the Syndent yielded relatively higher $(66,64 \%)$ than
Synflint $(63,00 \%)$ in relation to the check. The Syndent performed better than the Synflint material in this stress condition (WS), in which Syndent and the Synflint yielded $52,23 \%$ and $38,26 \%$ of the check, respectively. Normally, in some selected sites for drought research a reduction in yield around 60

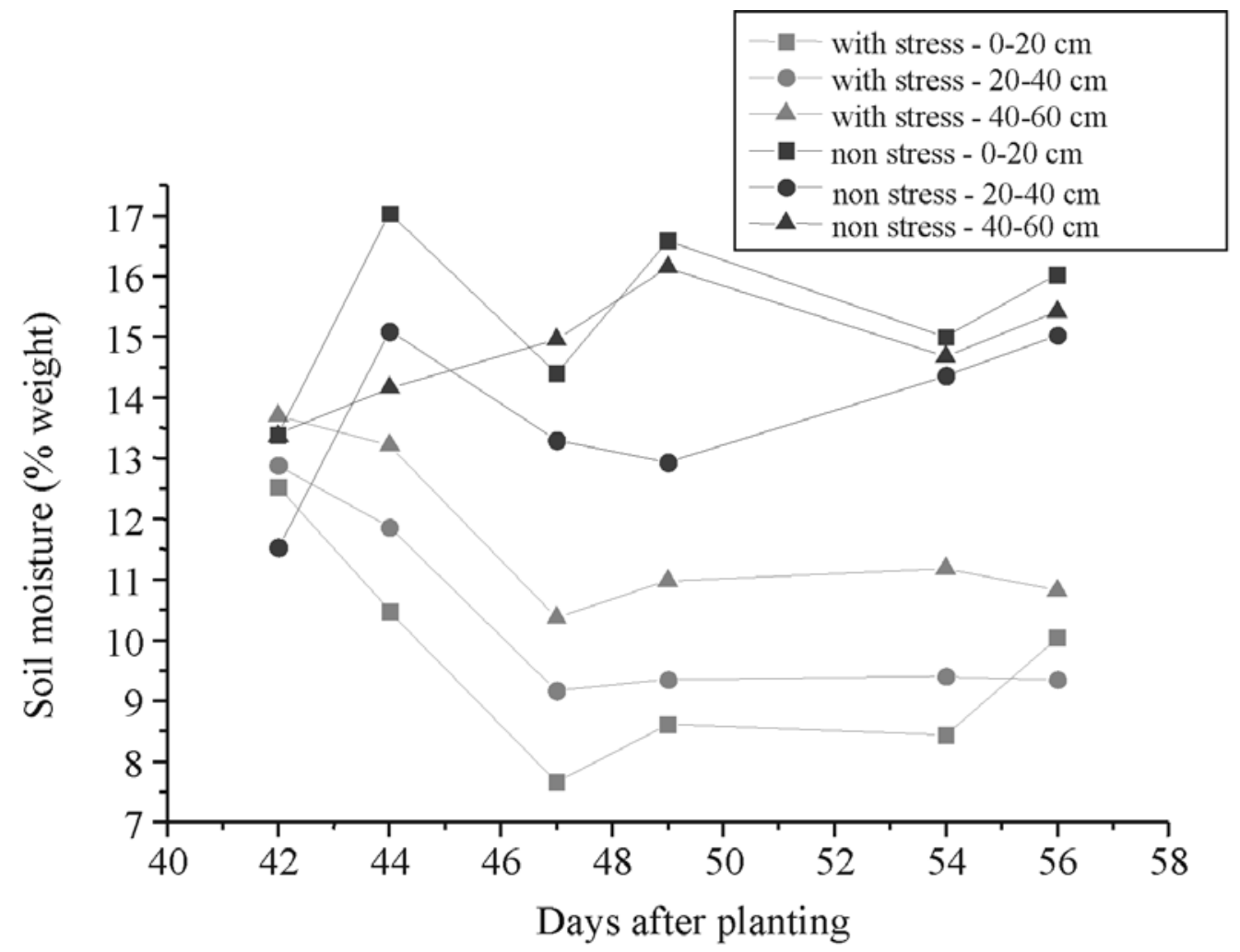

FIGURE 1. Soil water content profiles under two irrigation treatments, with and without water stress at preflowering stage, using a line source sprinkler system. Janaúba-MG, 2001.

TABLE 1. Mean square combined analysis results for ear yield $\left(\mathrm{kg} \mathrm{plot}^{-1}\right)$, in the two synthetics, evaluated at two water stress conditions, in Janaúba, MG, 2001.

\begin{tabular}{lccc}
\hline SV & DF & \multicolumn{2}{c}{ MS } \\
\hline & & Synflint & Syndent \\
Environment (E) & 1 & $328.8177^{* *}$ & $191.7071^{* *}$ \\
Progeny (P) & 143 & $0.7079^{* *}$ & $0.9494^{* *}$ \\
E x P & 143 & $0.3157^{* *}$ & $0.2851^{*}$ \\
Mean Error & 266 & 0.1933 & 0.3017 \\
\hline CV\% & & 20.08 & 21.68 \\
\hline Mean $\left(\right.$ kg plot $\left.^{-1}\right)$ & & 2,19 & 2.53 \\
\hline$*, * *$ significant at $\mathrm{P}<0.01$ and $\mathrm{P}<0.05$ levels, respectively. & & \\
\end{tabular}


TABLE 2. Broad-sense heritability $\left(h^{2}\right)$ genetic variance $\left(\sigma_{\mathrm{g}}^{2}\right)$, error variance $\left(\sigma_{\mathrm{e}}^{2}\right)$ and predicted response to selection $(\mathrm{R})$, for ear yield $\left(\mathrm{kg} \mathrm{plot}^{-1}\right)$, for two moisture stress environments, in Janaúba, MG, 2001.

\begin{tabular}{|c|c|c|c|c|c|}
\hline Experiments & Yield Mean & $\begin{array}{c}\mathrm{h}^{2} \\
\left(\mathrm{~kg} \mathrm{plot}^{-1}\right)^{2}\end{array}$ & $\begin{array}{c}\sigma_{g}^{2} \\
\left(\operatorname{kg~plot~}^{-1}\right)^{2}\end{array}$ & $\sigma_{\mathrm{e}}^{2}$ & $\begin{array}{c}\text { R } \\
\text { kg } \text { plot }^{-1}\end{array}$ \\
\hline Synflint (WS) & 1,433 & 0,382 & 0,054 & 0,196 & 0,532 \\
\hline Synflint (NS) & 2,945 & 0,752 & 0,289 & 0,171 & 1,157 \\
\hline Syndent (WS) & 1,956 & 0,607 & 0,157 & 0,270 & 0,806 \\
\hline Syndent (NS) & 3,110 & 0,635 & 0,235 & 0,204 & 1,046 \\
\hline Check (NS) & 6,985 & & & & \\
\hline Check (WS) & 3,344 & & & & \\
\hline
\end{tabular}

$\mathrm{WS}=$ With water stress; NS= non water stress; Check = Experimental double cross hybrid.

to $60 \%$ has been found with a stress applied at flowering, since genetic variation for tolerance and ear growth under stress is not clearly revealed until stress levels become severe (Edmeades et al., 1996).

The efficiency of selection under stress and non water stress conditions for increasing ear yields under water stress is determined by the broad-sense heritability $\left(\mathrm{h}^{2}\right)$ under water stress and non stress conditions (Bolaños and Edmeades, 1993).

Broad-sense heritability estimates of ear yield under non water stress exceeded those under water stress, and were 0.382 with stress and 0.752 without stress for Synflint, but showed similar trends for Syndent with 0.607 with stress and 0.635 without stress (Table 2). Betran et. al. (1997) and Bolaños $\&$ Edmeads (1997) found similar results $\left(\mathrm{h}^{2}>0.50\right)$ testing inbred lines of different endogamy levels, derived from CIMMYT germplasm under selection for drought resistance. The expected genetic variance estimates were lower in water stress condition than in non-water stress for both synthetics, mainly for Synflint material. The genetic variance under nonstress condition exceeded those with stress in 5.35 and 1.50 times on average for Synflint and Syndent, respectively. For this reason, gains in selection can only be possible when the genetic variation for tolerance to water stress, through whatever mechanism, can be observed (Bolaños \& Edmeades, 1997). Thus, even though the genetic variance estimated was not of large magnitude, better genetic gains could be obtained with the Syndent than with the Synflint material.

The error variance was a little higher under stress than without stress for both synthetics. Predicted response of ear yield of selection estimates showed a trend of higher values $\left(\mathrm{kg} \mathrm{plot}^{-1}\right)$ under non-stress treatment.

Larger predicted selection gains $(1,157 \mathrm{~kg}$ plot $\left.^{-1}\right)$ were found for Synflint and lower gain $(1,046$ $\left.\mathrm{kg} \mathrm{plot}^{-1}\right)$ for Syndent, both at non-stress conditions.

To identify superior endogamy progenies for the moisture stress imposed in the experiments, an analysis for genotype distributions was performed based on an environment index or water stress index (WSI) and yield under drought condition (Figures 2 and 3). According to the yield under water stress (ordinate) and the environment index (abscissa) we can place the progenies in four groups. Group 1, was classified as low yielding and non-tolerant to drought, characterized by low WSI and yield. It was composed of 31 progenies (22\%) and 24 progenies (17\%) for Syndent and Synflint, respectively.

Group 2, characterized by low WSI and high yield, composed of 48 progenies (33\%) and 47 
Figure 2 - Synflint

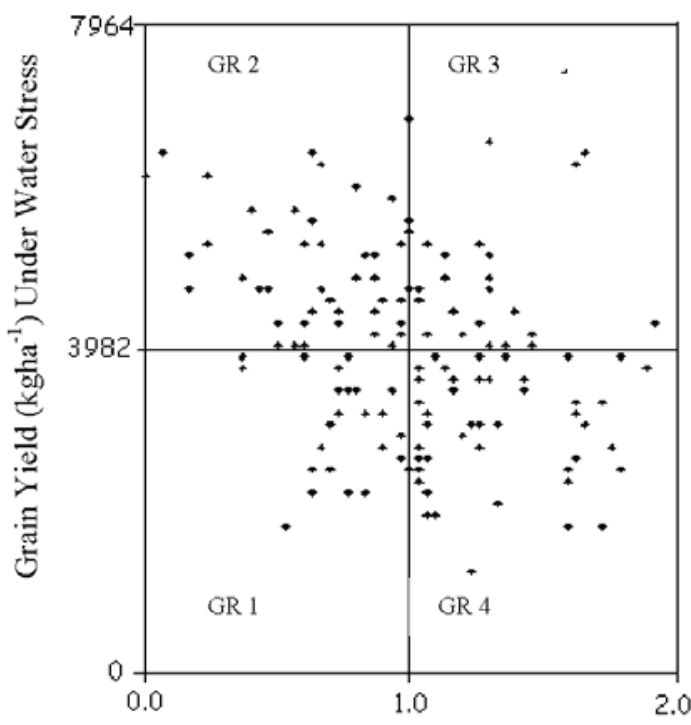

Environment Index

Figure 3 - Syndent

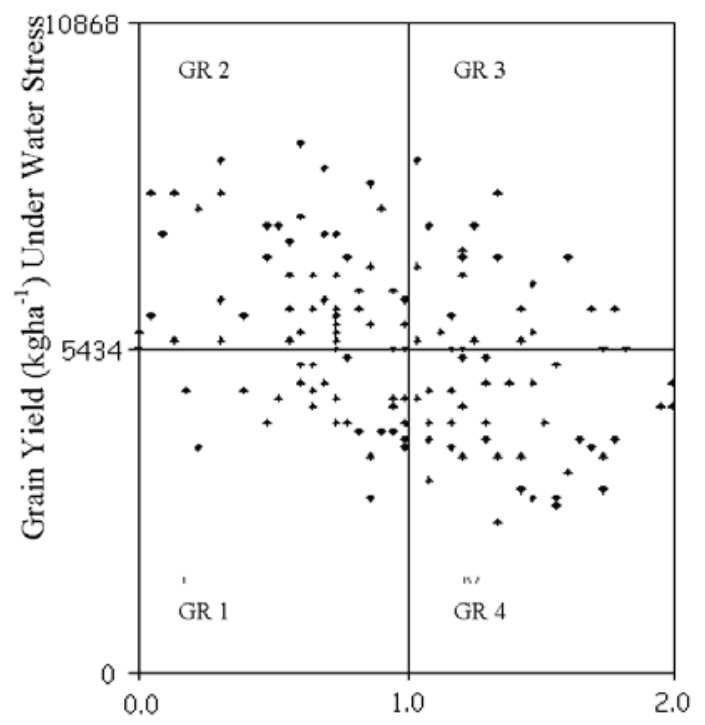

Environment Index

FIGURES 2 and 3. Ear yield as function of Water Stress Index - WSI, for 2 sets of 144 S2 progenies trials from 2 tropical synthetics (Synflint and Syndent), under two water regimes, in Janaúba, MG, Brazil, 2001. progenies (32.5\%) for Syndent and Synflint, respectively, and were classified as high yielding and non-tolerant to drought.

Group 3, characterized by high WSI and yield, composed of 22 progenies (15\%) and 26 progenies (18\%) for Syndent and Synflint, respectively, and were classified as high yielding and tolerant to drought.

Group 4, characterized by high WSI and low yield, composed of 43 progenies (30\%) and 47 progenies $(32.5 \%)$ for Syndent and Synflint, respectively, and were classified as low yielding and tolerant to drought.

The genotypes of interest are those of group 2. The progenies of this group will be used in continuing our breeding selection second phase.

The results found in this study showed the need to modify this scheme of selection with these two synthetics for yield improvement in this specific drought environment. Selection gains under low water can be considerably enhanced if secondary traits other than the yield are used when evaluating progenies in drought stress selection experiments. Selection under water stress conditions using topcross progenies and other traits related with drought besides yield should be a better strategy. This program has been the result of the increased pressure for input use efficiency and for yield, and increased availability of tropical adapt germplasm, for oriented hybrid production and open-pollinated synthetics development. Inter-population approaches can be used with these two synthetics for hybrid development, for example, by commercial seed companies. On the other hand, synthetic varieties compared with hybrids require less development time, have lower seed costs, are often more stable despite their lower yielding. These two synthetics could be released for farmers whose yields are reduced drastically by drought occurring near flowering and during grain filling periods. 


\section{Conclusions}

The Syndent materials were the most drought tolerant genotypes based on the low percentage of yield losses due to water stress, contrasting with Syndent progenies to Synflint progenies under drought stress.

Broad sense heritability estimates for Syndent were lower in the two environments than for the Synflint material.

There is a need to use secondary traits in addition to yield per se for selection, mainly reduction of ASI, in order to advance selection in these two synthetics.

These two synthetics can be used in hybrid programs since studies have shown that stresstolerant hybrids are often developed from stress tolerant sources and not from their conventionally selected counterparts.

\section{References}

BETRÁN, F. J.; BÄNZIGER, M.; BECK, D. L. Relationship between line and topcross performance under drought and non-stressed conditions in tropical maize. In: SYMPOSIUM OF DEVELOPPING DROUGHT AND LOW N-TOLERANCE MAIZE, 1996, El Batan, Mexico, Proceedings... Mexico: CIMMYT, 1997.p. 383-386. Editado por G. O. Edmeades, M. Banziger, H. R. Mickelson, C. B. Peña-Valdivia.

BLUM, A. Plant breeding for stress environment. Boca Raton: CRC Press, 1988.

BOLAÑOS, J.; EDMEADES, G. O. Eight cycles of selection for drought tolerance in lowland tropical maize. II. Responses in reproductive behavior. Field Crops Research,Amsterdam, v. 31,p. 253-268, 1993.

BOLAÑOS, J.; EDMEADES, G. O. Eight cycles of selection for drought tolerance in lowland tropical maize. I. Responses in grain yield biomes, and radiation utilization. Field Crops Research, Amsterdam, v. 31, p. 233-252, 1993.

BOLAÑOS, J.; EDMEADES, G. O. The importance of the anthesis-silking interval in breeding for drought tolerance in tropical maize. In: SYMPOSIUM OF DEVELOPPING DROUGHT AND LOW N-TOLERANCE MAIZE, 1996, El Batan, Mexico, Proceedings... Mexico: CIMMYT, 1997. p. 355-368. Editado por G. O. Edmeades, M. Banziger, H. R. Mickelson, C. B. Peña-Valdivia.

CEBALLOS, H.; PANDEY,Y.S. El cultivo del maiz en los países en via de desarrolo. In: CIMMYT. Experiencias en el Cultivo del Maiz en Areas Andina. Quito: PROCIANDINO, 1991a. p. 2728.

CEBALLOS, H.; Y S. PANDEY, Y. S. Sellecion recurrent en maizes tropicales. In: CIMMYT. Experiencias en el Cultivo del Maiz en el Area Andina. Quito: PROCIANDINO, 1991b. p. 3040 .

EDMEADES, G. D.; BÄNZIGER, M.; CORTES, C.; ORTEGA, A. From estress-tolerant populations to hybrids: The hole of sources germplasm. In: SYMPOSIUM OF DEVELOPPING DROUGHT AND LOW N-TOLERANCE MAIZE, 1996, El Batan, Mexico, Proceedings... Mexico: CIMMYT, 1997. p. 263-273. Editado por G.O. Edmeades, M. Banziger, H. R. Mickelson, C. B. Peña-Valdivia.

FALCONER, D. S. Introduction to quantitative genetics. 3.ed. London: Longman, 1989. 365 p.

FISCHER, R. A.; MAURER, R. Drought resistance in spring wheat cultivars. I. Grain yield responses. Australian Journal of Agricultural Research, Victoria, v. 29, p. 897-912, 1978.

HALLAUER, A. R.; MIRANDA FILHO, J. B. Quantitative genetics in maize breeding. Ames: Iowa University, 1981.469 p. 
HALL, A. J.; VILELLA, F.; TRAPANI, N.; CHIMENTI, C. The effects of water stress and genotype on the dynamics of pollen shedding and silking in maize. Field Crops Research, Amsterdam, v. 5, p. 349-363, 1982.

JOHNSON, S. S.; GEADELMANN, J. L. Influence of water stress on grain yield response to recurrent selection in maize. Crop Science, Madison, v. 29, p. 558-565, 1989.

LAMKEY, K. R.; HALLAUER, A. R. Herytability estimated from recurrent selection experiments in maize. Maydica, Bergamo, v. 31, p. 61-78, 1987.
ROSIELLE, A. A.; HAMBLING, J.Theoretical aspects of selection for yield in stress and non-stress environments. Crop Science, Madison, v. 21, p. 943-946, 1981.

SANTOS, M. X.; LOPES, M. A.; COELHO, A. M.; GUIMARÃES, P. E. O.; PARENTONI, S. N.; GAMA, E. E. G.; FRANÇA, G. E. Drought and low $\mathrm{N}$ status limiting maize production in Brazil. In: SYMPOSIUM OF DEVELOPPING DROUGHT AND LOW N-TOLERANCE MAIZE, 1996, El Batan, Mexico, Proceedings... Mexico: CIMMYT, 1997. p. 20-23. Editado por G. O. Edmeades, M. Banziger, H. R. Mickelson, C. B. Peña-Valdivia. 